PAWEE NowaK

Uniwersytet Pedagogiczny, Kraków

\title{
Funkcjonowanie sektora motoryzacyjnego w okresie kryzysu w latach 2008-2009
}

Ostatni światowy kryzys finansowy rozpoczął się w Stanach Zjednoczonych w połowie $2007 \mathrm{r}$. Wśród przyczyn kryzysu, podobnie jak tego z lat 20. i 30. XX w., w pierwszej kolejności wymienia się błędy w prowadzeniu polityki pieniężnej (Fiedman 2009, s. 83-97). Odejście od sprawdzonych historycznie reguł prowadzenia polityki z okresu poprzednich dwóch dekad spowodowało, a następnie pogłębiło i przedłużyło kryzys finansowy (Taylor 2010, s. 27). Źle prowadzona polityka pieniężna doprowadziła do boomu na rynku nieruchomości, po którym nastąpił głęboki regres. Załamanie w sektorze finansowym spowodowało ograniczenie akcji kredytowej banków i doprowadziło do spadku produkcji. Kryzys spowodował zagrożenie na niespotykaną dotąd skalę dla funkcjonowania wielkiej liczby przedsiębiorstw o kluczowym znaczeniu dla gospodarki (Bednarczyk, Bukowski, Misala 2009, s. 67). Sektor motoryzacyjny, ze względu na globalny charakter i wysoki stopień międzynarodowej współzależności, szybko znalazł się pod jego wpływem. Z pomocą gospodarkom ruszyły rządy, aby przeciwdziałać spadkowi produkcji i zatrudnienia. Środki interwencyjne zostały skierowane w pierwszej kolejności do sektora motoryzacyjnego.

\section{POZYCJA SEKTORA MOTORYZACYJNEGO W POLSKIEJ GOSPODARCE} W LATACH 2008-2009

Przemysł motoryzacyjny w Polsce należy do najważniejszych gałęzi gospodarki, o czym świadczy 9,4-procentowy udział w produkcji sprzedanej przemysłu w 2007 r., 9,5\% w 2008 i 9,7\% w 2009 r. Udział przemysłu motoryzacyjnego w eksporcie ogółem kształtował się okresie 2006-2008 na poziomie 16-17\%, a w eksporcie przemysłu na poziomie około 21,5\% (Raport 2010, s. 74).

Producenci samochodów to tylko wierzchołek piramidy. Na każdego pracownika zatrudnionego w produkcji samochodów przypada kilku pracowników zatrudnionych u kooperantów. Pod koniec trzeciego kwartału 2008 r. na rzecz przemysłu motoryzacyjnego pracowało w Polsce około 196 tys. osób (Raport 2009, s. 14). W Europie działa 250 fabryk samochodowych, które bezpośrednio zatrudniają $2,2 \mathrm{mln}$ osób, a razem z dostawcami około 12 mln osób - co stanowi 6\% wszystkich zatrudnionych w Unii Europejskiej. 
Produkcja krajowa kierowana jest głównie na eksport. W 2009 roku z powodu załamania popytu na rynkach zagranicznych odnotowano spadek wartości eksportu przemysłu motoryzacyjnego z 18,4 mld euro w 2008 r. do 15,7 mld euro. Stanowi to względny spadek o około $15 \%$. Spadek wartości eksportu wynikał ze spadku sprzedaży części i akcesoriów do samochodów osobowych o $15 \%$, silników o $25 \%$ oraz pojazdów specjalnych i nadwozi o ponad 80\% (Raport 2010, s. 16). Sprzedaż samochodów osobowych wyprodukowanych w Polsce na zagranicznych rynkach zwiększyła się o 1\%. W 2009 r. fabryki w Polsce wyprodukowały 869 tys. samochodów osobowych i dostawczych. Poziom produkcji był zbliżony do roku 2007 (Raport 2010, s. 14).

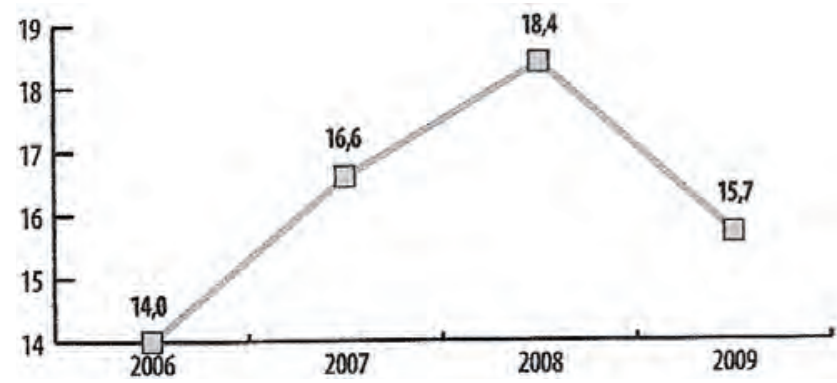

Ryc. 1. Eksport przemysłu motoryzacyjnego (mld euro)

Źródło: Raport 2010, s. 15

Niewielka część produkcji krajowej kierowana jest na rynek krajowy, blisko 98\% produkcji sprzedawane jest na rynkach zagranicznych, w 2008 r. wynosił 96,92\% (Raport 2009, s. 12). Głównymi odbiorcami są Unia Europejska, do której trafia około 90\% eksportu. Z krajów pozaunijnych ważne miejsca zajmuje eksport na Ukrainę i do Rosji. Spośród krajów europejskich największym rynkiem zbytu dla przemysłu motoryzacyjnego są niezmiennie od lat Niemcy. W wyniku dopłat wprowadzonych przez rządy największych gospodarek unijnych udział eksportu na rynek unijny w całości eksportu zwiększył się o blisko 8\% w 2009 r. w porównaniu z rokiem poprzednim.

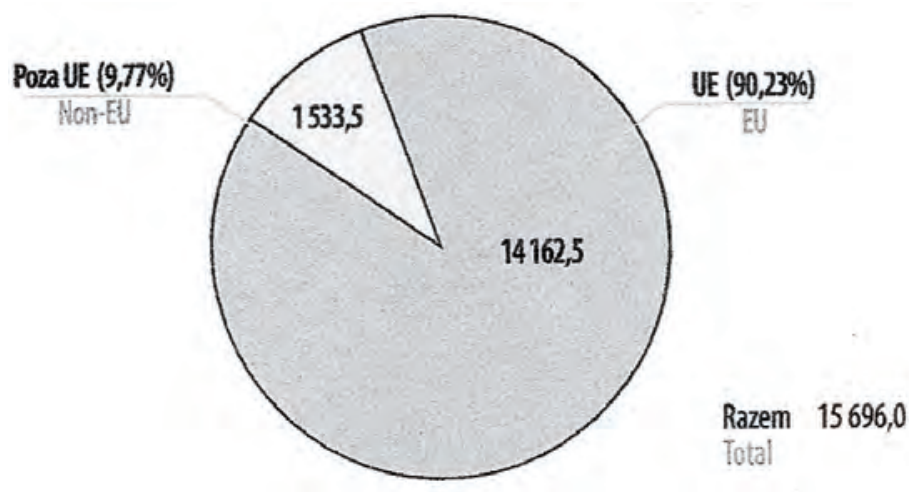

Ryc. 2. Kierunki eksportu przemysłu motoryzacyjnego w 2009 r. 
Polska jest jednym z największych producentów samochodów i podzespołów w regionie Europy Środkowej i Wschodniej. Z polskich fabryk pochodzi co dwudziesty samochód i co siódmy autobus wyprodukowany w Europie. Z 40 fabryk zajmujących się montażem samochodów lub silników w tej części Europy 16 znajduje się Polsce. Polska jest drugim co do wielkości producentem samochodów. Pierwszym są Czechy z produkcją 967,8 tys., a trzecim Słowacja - 461,3 tys. samochodów (Raport 2010, s. 71).

Eksport przemysłu motoryzacyjnego tworzą zasadniczo trzy produkty: samochody osobowe i ciężarowe, części oraz silniki wysokoprężne. Największy udział w eksporcie mają samochody osobowe i ciężarowe - około 50\%, drugie miejsce zajmuje sprzedaż części - około $35 \%$, a pozostałą część stanowią silniki wysokoprężne - około 15\%. Eksport części rósł do 2008 r. w tempie około 25\% rocznie. Największymi odbiorcami części i akcesoriów są Włochy i Niemcy, na które przypada 45\% eksportu. Blisko 20 mld uzyskanych przez przemysł motoryzacyjny z eksportu przypada na producentów części (Cała prawda...).

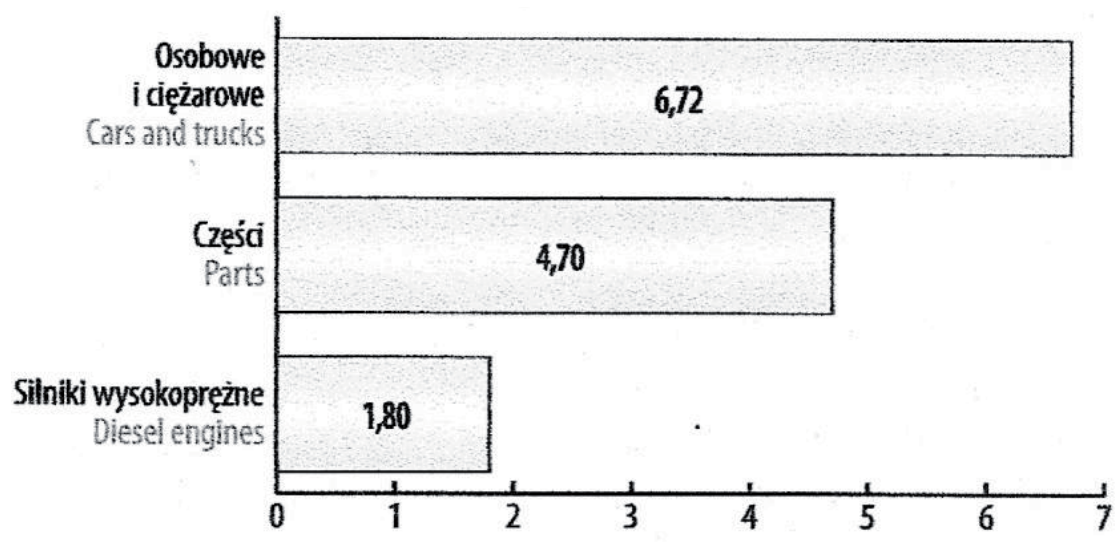

Ryc. 3. Struktura polskiego eksportu według głównych produktów w 2009 r. (mld euro)

Źródło: Raport 2010, s. 16

Najwięcej samochodów produkuje w Polsce od lat Fiat Auto Poland (obecnie modele Panda i 500 oraz dla Forda model Ka), co stanowi prawie 70\% łącznej krajowej produkcji samochodów.

Głównym rynkiem zbytu dla całego polskiego przemysłu motoryzacyjnego (samochody osobowe i ciężarowe, części i silniki wysokoprężne) są rynki krajów UE, w tym głównie rynek niemiecki. Niemcy są największym odbiorcą części, natomiast Włochy są największym importerem samochodów. Powiązanie gospodarcze z gospodarką niemiecką sektora motoryzacyjnego, podobnie jak wielu innych sektorów naszej gospodarki, jest bardzo silne. Sytuacja w gospodarce niemieckiej ma ogromny wpływ na koniunkturę w naszym kraju. Kolejne pozycje w rankingu zajmują: Francja, Wielka Brytania i Czechy.

Znaczenie rynku krajowego dla krajowych producentów aut jest znikome. Tylko 2-3\% całkowitej produkcji znajduje nabywców na rynku krajowym. W sprzedaży krajowej od lat dominują samochody importowane. W 2008 r. sprzedaż samochodów nowych na rynku krajowym wyniosła ponad 300 tys. sztuk i była prawie czterokrotnie mniejsza od sprzedaży samochodów używanych. W trudnym dla światowej gospodarki 2009 r. polskiemu przemysłowi motoryzacyjnemu udało się utrzymać wartość sprzedaży na poziomie zbliżonym do 
2008 r. Według danych PZPM, w 2009 r. importerzy sprzedali 320120 samochodów osobowych, o 198 sztuk więcej niż w 2008 r. (Raport 2010, s. 17).
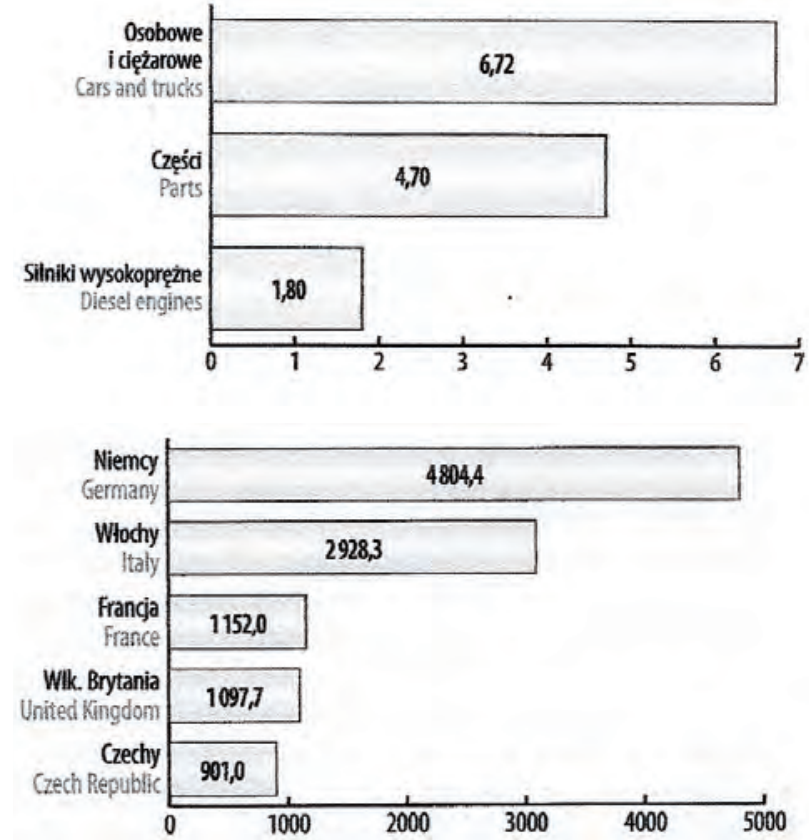

Ryc. 4. Główne rynki zbytu polskiego przemysłu motoryzacyjnego w 2009 r. (mln euro])

Źródło: Raport 2010, s. 16

Sprzedaż nowych samochodów w Polsce jest stosunkowo mała w odniesieniu do wielkości populacji. W bogatych krajach Europy Zachodniej nawet w czasie kryzysu sprzedaje się około 30 samochodów na tysiąc mieszkańców. W Polsce ten wskaźnik jest blisko 4 razy mniejszy. Rekordową sprzedaż nowych samochodów odnotowano w 2003 r., gdy na rynku krajowym sprzedano ponad 350 tys. sztuk. Potencjał polskiego rynku jest ponadtrzykrotnie większy, biorąc pod uwagę wskaźniki dla zamożnych krajów Europy Zachodniej, sprzedaż powinna sięgać około $1 \mathrm{mln}$ rocznie.

Inwestorzy z branży motoryzacyjnej chętnie lokują działalność na terenie Specjalnych StrefEkonomicznych (SSE). W Polsce istnieje 14 SSE. W największej katowickiej SSE zlokalizowanych jest 18 firm motoryzacyjnych, w tym największe General Motors Manufacturing Poland Sp. z o.o. i Fiat - GM Powertrain Polska Sp. z o.o. Po katowickiej na drugim miejscu są legnicka i wałbrzyska SSE, w obrębie których działa po 7 firm. Pod względem wielkości inwestycji sektor motoryzacyjny ma pozycję lidera w Specjalnych Strefach Ekonomicznych. Do końca 2009 r. firmy motoryzacyjne zainwestowały w strefach 17,5 mld zł, co stanowi 26\% łącznych nakładów inwestycyjnych w SSE. W 2008 r. nakłady wyniosły 16 mld zł, co stanowiło 29\% łącznych nakładów w strefach (Raport 2009, s. 60).

Raport Przejściowa zadyszka...? Polskie SSE - okiem przedsiębiorcy z 2010 r. zawiera analizę wyników drugiej edycji badania przeprowadzonego przez Deloitte, dotyczącego opinii przedsiębiorców prowadzących działalność w SSE. Podsumowuje nastroje panują- 
ce wśród osób odpowiedzialnych za prowadzenie biznesu na terenie SSE. Z raportu wynika, że SSE mogą być nadal magnesem przyciągającym inwestycje. Aż 67,8\% uczestników badania uznało, że rozpoczynając nowy projekt inwestycyjny, ubiegałoby się o zwolnienie w SSE (Raport: Polskie SSE... 2010, s. 15). Jednocześnie tylko 7,9\% badanych zdecydowanie odrzuciło zasadność prowadzenia kolejnej inwestycji w SSE. Atrakcyjność inwestycyjna w SSE nie zakończyła się w 2008 r. i SSE są nadal zdolne do przyciągnięcia dużych kapitałochłonnych inwestycji.

Efektywność podatkowej ulgi strefowej dla przedsiębiorstw nie jest jednak wysoka. Wyniki badania Deloitte potwierdzają, że większość przedsiębiorców strefowych nie wykorzysta przysługującej im ulgi w podatku dochodowym, aż $27,7 \%$ biorących udział w badaniu mimo prowadzonych lub nawet zakończonych inwestycji nie uzyskało jeszcze żadnego benefitu podatkowego, w skali ogólnokrajowej około 75\% inwestorów nie ma szans na wykorzystanie przysługującej im ulgi strefowej.

Mechanizm zachęty inwestycyjnej w postaci lokowania biznesu w SSE jest efektywny w dłuższej perspektywie czasowej. Największe trudności przedsiębiorstwa mają z utrzymaniem zadeklarowanego poziomu zatrudnienia. Postulowane przez Ministerstwo Gospodarki złagodzenie wymogu zatrudnienia wpisuje się w oczekiwania przedsiębiorców. Brak liberalizacji przepisów w tym względzie może w dłuższej perspektywie czasowej doprowadzić do utraty zezwolenia przez znaczny odsetek obecnych inwestorów, co w wielu przypadkach może prowadzić do zakończenia działalności gospodarczej w ogóle i tym samym zagrożenia istnienia $75-80 \%$ nowo utworzonych miejsc pracy. Brak odpowiednich zmian legislacyjnych doprowadzić może do sytuacji, kiedy inwestor de facto nigdy nie uzyska deklarowanej wcześniej pomocy.

\section{REAKCJA PRODUCENTÓW NA KRYZYS I DZIAŁANIA STABILIZACYJNE RZĄDÓW}

W wyniku kryzysu część firm wyhamowało inwestycje, sprzedało swoje zakłady lub wycofało się z Polski. W 2008 r. część zakładów zmniejszyła produkcję poprzez rezygnację $\mathrm{z}$ trzeciej zmiany, skracanie tygodnia pracy z pięciu do czterech dni lub wprowadzenie przestojów technicznych. Fala zwolnień objęła około 6 tys. pracowników (Raport 2010, s. 14). Remy Automotive Poland zlikwidował zakład w Świdnicy, a IAC Group zamknął fabrykę w Teresinie. Zwolnienia miały miejsce w dwóch fabrykach produkujących przewody w Wielkopolsce: SEWS Polska i Leoni Autokabel Polska. Spółka Groclin-Auto przeniosła produkcję foteli samochodowych na Ukrainę. W latach 2006 i 2007 we Francji zlikwidowano prawie 10 tys. miejsc pracy u producentów i dostawców (Branża..., s. 1).

Kryzys spowodował rozszerzenie zdolności produkcyjnych w tzw. strefach low cost. Francuska PSA przeniosła do Czech produkcję modeli 107 i C1, a na Słowację modelu 207 i C3 Picasso. Koncern Renault produkuje modele Twingo i Clio Campus w Słowenii, a Clio Estate w Turcji. Przeniesienie produkcji wynika z działań ekonomicznych i strategicznych. Mają one na celu przywrócenie rentowności, która w latach 2008-2009 pogorszyła się ze względu na podwyżki cen surowców zwłaszcza stali.

Szczególnie ważne dla perspektyw polskiego przemysłu motoryzacyjnego są zamierzenia koncernu Fiata, producenta prawie trzech czwartych wszystkich samochodów w Polsce. Niestety według zapowiedzi zarządu Fiata nowa Panda nie będzie produkowana w Polsce 
tylko w zakładach Pomigliano pod Neapolem. Ponadto Fiat przenosi do Serbii nowego multiwana, który zastąpi Ideę i Multiplę. 70\% kosztów inwestycji weźmie na siebie rząd w Belgradzie, Włosi przez dziesięć lat zwolnieni będą z podatków, otrzymają po 10 tys. euro za każdego zatrudnionego robotnika, jemu zaś płacić będą równowartość 400 euro miesięcznie (Plany...).

Załamanie koniunktury na przełomie roku 2008 i 2009 mogło doprowadzić do katastrofy gospodarczej. Rządy trzynastu krajów unijnych zdecydowały się na wprowadzenie pomocy gospodarczej. Premie za złomowanie starych aut wynosiły od 750 do 6500 euro. Dopłaty wprowadziły m.in. Niemcy (po 2,5 tys. euro za wymianę dziewięcioletniego lub starszego auta), Francja i Włochy (po tysiąc euro za wymianę aut dziesięcioletnich i starszych). Natomiast Hiszpania zaproponowała nieoprocentowany kredyt do 15 tys. euro na zakup samochodu przyjaznego dla środowiska. Słowacja przeznaczyła z budżetu $33 \mathrm{mln}$ euro na dopłaty (w wysokości 2000 tys. euro dla każdego, kto kupi nowy samochód i odda stary, co najmniej dziesięcioletni (Auta...). Znaczenie dopłat potwierdzają dane, W 2009 r. do krajów unijnych, w których wprowadzono dopłaty, polski eksport spadł o $6 \%$, natomiast do krajów pozaunijnych spadek eksportu wyniósł aż 44\%. W 2009 r. co szósty nowy samochód kupiony w Polsce był wywożony za granicę, głównie do Niemiec, gdzie popyt był stymulowany przez dopłaty niezależnie od kraju pochodzenia samochodu. W poprzednich latach odsetek samochodów sprzedanych w kraju zagranicznym klientom nie przekraczał kilku procent i wynikał głównie ze słabego złotego.

Szacuje się, że około 35\% nowych rejestracji w Niemczech, 20-25\% we Francji oraz 70\% Wielkiej Brytanii zostało dokonanych dzięki zachętom finansowym. W krajach, w których nie wprowadzono pomocy państwa, wystapił spadek rejestracji nowych samochodów w Belgii o 14\% i $80 \%$ na Łotwie. Natomiast w Niemczech liczba rejestracji nowych samochodów wzrosła za cały 2009 r. o 23,2\%, we Francji o 10,7\%, w Austrii o 8,8\% i w Czechach o 12,5\%. Dzięki dopłatom liczba rejestracji nowych samochodów w Europie spadła w 2009 roku tylko o $1,6 \%$.

\section{PERSPEKTYWY NA PRZYSZLOŚĆ}

Ostatnie miesiące 2010 r. przyniosły niepokojące sygnały z Europy Zachodniej. Podczas, gdy produkcja pięciu państw regionu Europy Środkowej i Wschodniej i ich eksport doszedł do szczytowego punktu sprzed recesji, sprzedaż samochodów w Europie Zachodniej osłabła do bliskiego recesji poziomu z przełomu 2008-2009. Prawdopodobnym powodem było to, że zakupu samochodów dokonano wcześniej, by zdążyć przed upływem rządowego planu wsparcia zakupu nowych samochodów. Spadek dynamiki sprzedaży w następstwie wygaśnięcia rządowych programów wymiany starych samochodów na nowe jest zauważalny.

Perspektywy polskich zakładów poprawia fakt, że produkują one małe i średnie samochody na które istnieje większy popyt w czasie spowolnienia gospodarczego. W $2009 \mathrm{r}$. wyraźnie zwiększył się udział samochodów małych w sprzedaży w całej Europie o 6,2\% do $45 \%$. Ponadto perspektywy poprawia wzrost w UE na początku $2010 \mathrm{r}$. liczby rejestracji marek wytwarzanych w Polsce. AutomotiveSuppliers.pl prognozuje, że w całym $2010 \mathrm{r}$. wartość eksportu przemysłu motoryzacyjnego w Polsce osiagnie poziom 17-17,4 mld euro, co oznacza 8-10\% wzrost w stosunku do roku poprzedniego (Lipiec 2010 ...). 
Przyszłość polskiego sektora motoryzacyjnego zależeć będzie od tego, czy uda się utrzymać istniejące fabryki i czy Polska będzie skutecznie konkurować z innymi krajami o nowe inwestycje zagraniczne. W 2008 r. zanotowano ujemne saldo napływu zagranicznych inwestycji bezpośrednich do sektora motoryzacyjnego. Koncerny zagraniczne dla pokrycia strat odnotowanych przez zakłady w innych krajach nie reinwestowały zysków w Polsce. W 2009 r. napływ bezpośrednich inwestycji zagranicznych zmalał o 17,7\% (Raport 2010, s. 69). Niepokojące jest to, że Polska w ostatnich latach nie ściągnęła żadnej poważnej inwestycji zagranicznej. Toyota zlokalizowała produkcję w Czechach, a Hyundai/KIA na Słowacji. Perspektywy inwestycyjne Polski opierają się w coraz większym stopniu na planach producentów części. Nowe inwestycje w Katowickiej SSE zapowiedział włoski koncern Brembo produkujący tarcze hamulcowe oraz Lear Corporation produkujący fotele. Kolejne inwestycje pojawią się w Wałbrzyskiej SSE (produkcja poduszek powietrznych przez Autoliv Poland, rozbudowa zakładu produkującego elementy klimatyzacji przez Trelleborg Automotive) i Kostrzyńsko-Słubickiej SSE (produkcja przyczep przez firmę Henschel) (Produkcja...).

W celu poprawy warunków działania rząd próbuje uelastycznić wymagania w SSE. $\mathrm{Na}$ początku 2009 r. Ministerstwo Gospodarki przygotowało projekt nowelizacji Ustawy o specjalnych strefach ekonomicznych, który zakłada m.in. możliwość zmiany zezwoleń strefowych poprzez obniżenie wymogów zatrudnienia, możliwość uzyskiwania zezwoleń na nowy projekt bez wymogu utworzenia nowych miejsc pracy czy też zliberalizowanie wyśrubowanych kryteriów tworzenia stref na gruntach prywatnych. Branża liczy na zastapienie akcyzy podatkiem uzależnionym od parametrów ekologicznych i uregulowanie przepisów dotyczących możliwości odliczania VAT od pojazdów firmowych.

Przewaga konkurencyjna Polski nad pozostałymi czterema krajami Europy Środkowej i Wschodniej opiera się głównie na stosunkowo taniej, dobrze wykwalifikowanej i licznej sile roboczej. Zasoby siły roboczej są w Polsce ponad trzy razy większe niż razem w Czechach i na Węgrzech i ponad osiem razy większe niż w Słowacji. Przewaga Polski pod względem ceny pracy na tle pozostałych krajów regionu nie jest już tak wyraźna. Wynagrodzenie w Polsce jest wprawdzie niższe niż w Czechach, ale wyższe niż w pozostałych krajach.

Inwestorzy przy decyzjach biorą pod uwagę więcej czynników, m.in. wsparcie państwa, poziom biurokracji, ceny ziemi i system podatkowy. Polska pod względem atrakcyjności inwestycyjnej nie wypada najlepiej. W rankingu Banku Światowego Doing Business na 2011 r. Polska uplasowała się na 70 miejscu w świecie wśród 183 krajów (Polska...). W grupie 5 krajów producentów motoryzacyjnych w Europie Środkowej i Wschodniej Polska zajęła ostatnie miejsce. Najwyżej uplasowała się Słowacja (41 miejsce), następnie Węgry (46 miejsce), Rumunia (56 miejsce) i Czechy (63 miejsce).

Brak przejrzystości w podejmowaniu decyzji przez organy administracji to jedna z głównych barier w napływie inwestycji zagranicznych do Polski. Firmy lokujące swoje przedsięwzięcia w Polsce narzekają również na sposób funkcjonowania systemu zachęt inwestycyjnych oraz brak planów zagospodarowania przestrzennego. Inwestorzy wśród barier ograniczających napływ zagranicznych inwestycji wymieniają także długie procedury uzyskiwania zezwoleń na pracę i legalizację pobytu przez cudzoziemców (Zagraniczne...). 


\begin{tabular}{|c|c|c|c|c|c|}
\hline$\stackrel{ \pm}{\tilde{\Xi}}$ & $\stackrel{\infty}{\varrho}$ & $\cong$ & $\Xi$ & $\stackrel{\circ}{2}$ & $\tilde{\approx}$ \\
\hline$\stackrel{m}{\tilde{N}}$ & $\cong$ & ભે & 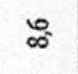 & $\stackrel{m_{2}}{m}$ & $\approx$ \\
\hline 芩 & $\stackrel{\square}{0}$ & $\stackrel{\infty}{\cong}$ & $\stackrel{\infty}{\sim}$ & $\bar{\beth}$ & $\stackrel{\simeq}{=}$ \\
\hline$\overline{\bar{\nu}}$ & i & $\equiv$ & $\stackrel{8}{1}$ & $\stackrel{\circ}{\circ}$ & $\bar{\Xi}$ \\
\hline 윰 & $\hat{m}$ & $\stackrel{\infty}{\varrho}$ & $\because$ & 음 & $\alpha^{2}$ \\
\hline ક્ّે & $\stackrel{m}{m}$ & $\stackrel{\infty}{\circ}$ & 8 & $\approx$ & $\sigma^{2}$ \\
\hline 芯 & $\underset{z}{Z}$ & ‡ి & 6 & $\stackrel{\circ}{\circ}$ & $\stackrel{\circ}{\varrho}$ \\
\hline ธ్ర్జ & $\equiv$ & $\approx$ & $\ddot{\circ}$ & $\stackrel{2}{2}$ & 2 \\
\hline 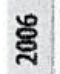 & $\tilde{m}$ & $\stackrel{2}{2}$ & \& & 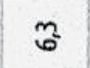 & $\approx$ \\
\hline 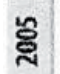 & జ & $\approx$ & $\tilde{m}$ & $n^{2}$ & $\approx$ \\
\hline ఫ્ّ̆ & $\stackrel{m}{\sim}$ & $\bar{\sigma}$ & $\approx$ & $F$ & $\ddot{\infty}$ \\
\hline 哭 & ส & $\approx$ & 유 & $\stackrel{\infty}{m}$ & $\stackrel{\infty}{n}^{\infty}$ \\
\hline ธ్ జี & $\bar{E}$ & $\overline{v i}$ & $\stackrel{\circ}{=}$ & $\ddot{\sim}$ & $\mathscr{*}$ \\
\hline ఫ్ల & 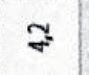 & $\stackrel{\infty}{\sim}$ & $\Xi$ & $\approx$ & $\stackrel{0}{m}$ \\
\hline ఫ్రై & $\stackrel{0}{m}$ & $\dddot{7}$ & $\underline{2}$ & $\bar{i}$ & $\bar{m}$ \\
\hline g & $\stackrel{D}{n}$ & 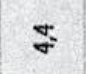 & & ন & $\stackrel{m}{m}$ \\
\hline$\stackrel{\circ}{\circ}$ & $\bar{m}$ & 7 & & $\ddot{\sim}$ & $\stackrel{\vec{m}}{*}$ \\
\hline$\Phi$ & 雍 & ले & & $\overleftarrow{\sim}$ & $\stackrel{p}{m}$ \\
\hline 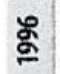 & $\stackrel{\circ}{n}$ & 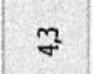 & & $\ddot{\sim}$ & $\stackrel{\infty}{m}$ \\
\hline & 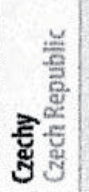 & 혈 & 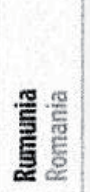 & 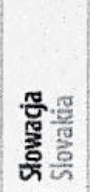 & " \\
\hline
\end{tabular}




\section{WNIOSKI}

Polska wyszła obronną ręką z kryzysu odczuwając jedynie spowolnienie gospodarcze. Jako jeden z nielicznych krajów w świecie odnotowała w 2009 r. dodatnią dynamikę zmian PKB. Rząd w Polsce nie zdecydował się na wprowadzenie dopłat do zakupu nowych samochodów. Strategia, która powiodła się w innych krajach, w Polsce nie miałaby sensu. Wpływ dopłat na produkcję w Polsce byłby znikomy, ponieważ o jej wielkości decyduje popyt zagraniczny, a nie krajowy.

W świecie interwencje rządów zahamowały rozwój kryzysu. Dzięki ogromnym wydatkom publicznym udało się zatrzymać i odwrócić trend spadkowy. Problemu nie udało się jednak trwale rozwiązać. Kryzys finansowy przeobraził się w kryzys finansów publicznych. Pomoc rządów doprowadziła do powstania ogromnych deficytów i długów sektora finansów publicznych. Nierównowaga finansów publicznych stała się niebezpieczna dla krajów i ich społeczeństw. Stąd konieczność podejmowania dalszych działań przywracających równowagę makroekonomiczną.

\section{Literatura}

Auta drożeja, ale dopłat nie ma, http://www.motofakty.pl/artykul/auta_drozeja_ale_doplat_nie_ma.html Bednarczyk J.L. ,Bukowski S.I., Misala J., 2009, Wspótczesny kryzys gospodarczy, CeDeWu, Warszawa.

Branża motoryzacyjna $w$ stagnacji, http://www.egospodarka.p1/34766,Branza-motoryzacyjna-w-stagnacji,3,39,1.html

Cała prawda o branży motoryzacyjnej, http://moto.onet.pl/1603773,1,cala-prawda-o-branzy-motoryza cyjnej, artykul.html?node $=6$

Fiedman M i R., 2009, Wolny wybór, Wydawnictwo Aspekt, Sosnowiec.

Lipiec 2010: eksport przemystu motoryzacyjnego zaczyna hamować?, http://www.automotivesuppliers.pl/index.php?option=com_content\&view=article \&id=5987\%3Alipiec-2010-eksport-przemysu-motoryzacyjnego-zaczyna-hamowa \&catid $=911 \% 3$ Awydarzenia\&Itemid $=81 \&$ lang $=\mathrm{pl}$

Plany fiata znów wywołały burze we Włoszech, http://moto.money.pl/wiadomosci/aktualnosci/artykul/ plany;fiata;znow;wywolaly;burze;we;wloszech,118,0,647542.html

Polacy nie dostanq dopłat do samochodów, http://gospodarka.dziennik.pl/news/artykuly/159686, polacy-nie-dostana-doplat-do-samochodow.html

Polska dopiero na 70 miejscu w światowym rankingu ułatwień dla biznesu, http://biznes.gazetaprawna.pl/grafika/463304,51646,doing_business_2011_polska_dopiero_na_70_miejscu_w_swiatowym_rankingu_ulatwien_dla_biznesu.html

Produkcja części samochodowych wspiera polski przemyst motoryzacyjny, http://motoryzacja.wnp.pl/ produkcja-czesci-samochodowych-wspiera-polski-przemysl-motoryzacyjny,108133_1_0_0.html

Raport branży motoryzacyjnej 2009, http://www.pzpm.org.pl/pl/6-72/0/180/raport-branzy-motoryzacyjnej-2009

Raport branży motoryzacyjnej 2010, http://www.pzpm.org.pl/pl/6-72/0/258/raport-branzy-motoryzacyjnej-2010

Raport Polskie SSE - okiem przedsiębiorcy 2010, http://www.deloitte.com/view/pl_PL/pl/uslugi/ doradztwo-podatkowe/zwolnieniapodatkowewsse/ab442781d1489210VgnVCM100000ba 42f00aRCRD.htm

Taylor J. B., 2010, Zrozumieć kryzys finansowy, Wydawnictwo Naukowe PWN, Warszawa. 
Zagraniczne inwestycje hamowane przez biurokracje, http://www.podatki.biz/sn_autoryzacja/logowanie.php5/artykuly/16_12431.htm?idDzialu=16\&idArtykulu=12431http://www.podatki.biz/ sn_autoryzacja/logowanie.php5/artykuly/16_12431.htm?idDzialu=16\&idArtykulu=12431

\section{The automotive industry in times of economic crisis in years 2008-2009}

This paper presents the complexity of the past two years in the Polish automotive industry and the impact and consequences of the economic downturn. The last two years were extremely challenging for the entire economy, especially the motor industry. The demand for cars decreased at the turn of 2008 and 2009. A dramatic plunge in sales has immediately taken a toll on suppliers and an entire economy. To prevent economic disaster, governments of many states allocated billions of euros and dollars to fund stimulating plans for buyers of the new vehicles. It was an aid which largely saved the sector from the decline. The additional aid packages for the entire economy and the financial sector managed to stabilize the disrupted economy.

Dr Paweł Nowak

Uniwersytet Pedagogiczny, Kraków

Instytut Politologii

Katedra Ekonomii i Polityki Gospodarczej

e-mail: gelb@wp.pl 